\title{
Spontaneous rupture of the splenic artery aneurysm: a rare clinical presentation of acute abdomen
}

\author{
Mehmet Timuçin Aydın, M.D., Mehmet Mahir Fersahoğlu, M.D., Sinan Tezer, M.D., \\ Mehmet Okuducu, M.D., Birol Ağca, M.D., Kemal Memişoğlu, M.D.
}

Department of General Surgery, Fatih Sultan Mehmet Training and Research Hospital, İstanbul, Turkey

\begin{abstract}
Splenic artery aneurysms are very rare causes of acute abdomen but are important to recognize since they carry high rate of mortality when ruptured. The aim of this study was to present a middle aged man with sudden onset of abdominal pain. Being previously on steroid treatment due to sarcoidosis, the patient developed hypovolemic shock during work-up in diagnostic imaging and went on emergency laparatomy. The source was identified as a ruptured splenic artery aneurysm. Splenectomy en bloc with the aneurysmatic distal splenic artery was performed, and he was discharged uneventfully. Despite rare, it is important to recognize splenic artery aneurysm in the emergency department, and immediate intervention is required to save the patient.
\end{abstract}

Keywords: Acute abdomen; aneurysm; rupture; splenic artery.

\section{INTRODUCTION}

Acute abdominal pain is one of the most frequent complaints encountered in emergency departments. The differential diagnosis is made from a quite long list, and some pathologies are so infrequent that one may overlook them. Although it is the third most common abdominal aneurysm after aortic and iliac artery aneurysms, splenic artery aneurysm (SAA) is an uncommon and a quite rare clinical diagnosis in emergency department admissions. ${ }^{[1]}$ They may be congenital or acquired conditions, and atherosclerosis, hypertension, trauma, and septic embolism play role in the development of SAA. [2] Pregnancy and multiparity are known as risk factors in the development of SAA, and indeed, SAA is frequent in female patients. The patient may be asymptomatic, but the rupture is catastrophic and carries high mortality, especially during pregnancy, both maternal and fetal compromise are frequent unless diagnosed and managed timely. ${ }^{[2,3]}$

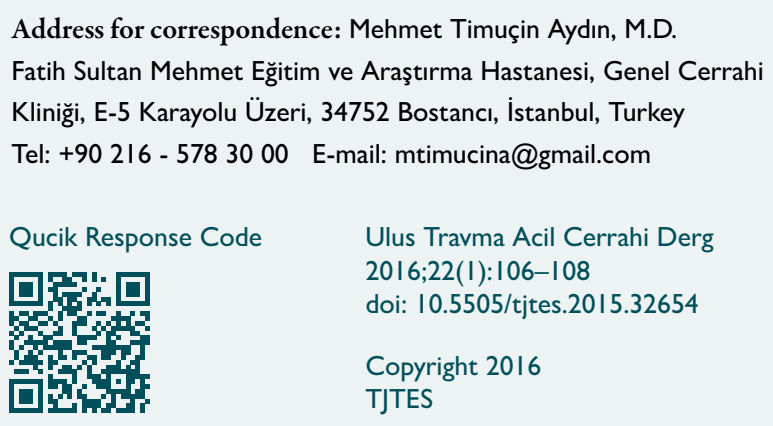

The aim of this study was to present a case who was admitted to the emergency department with sudden onset of abdominal pain and later developed shock.

\section{CASE REPORT}

A 33-year-old male with a known history of pulmonary sarcoidosis on steroid therapy presented to the emergency department with acute left upper quadrant - left flank pain and nausea of about 3 hours duration. The patient was pale and sweating and uneasy while lying down on the table. There was no history of trauma, and the patient told that he was otherwise healthy. He was slightly hypotensive with a blood pressure of $100 / 70 \mathrm{mmHg}$ and tachycardic. Initial abdominal examination revealed tenderness on epigastrium and left upper quadrant andrigid guarding with rebound tenderness mimicking an episode of hollow viscus perforation. The costa-vertebral angle tenderness was questionable and bowel sounds were hypoactive. Digital examination was unremarkable.

Laboratory findings disclosed leucocytosis (WBC: 29990/ $\mathrm{mL}$ ), a low hemoglobin level ( $\mathrm{Hb}$ : $1 \mathrm{I} .8 / \mathrm{dL}$ ) and normal platelet count. Chest $X$-ray was normal without any signs of subdiaphragmatic free air, and strip urinalysis were inconclusive. The patient was referred to the radiology department for a computerized abdominal tomography (CAT) which showed a rim of free fluid around the liver in addition to an irregular non-homogenous mass lesion around the greater curvature of the stomach that was initially considered as a confined tumor perforation. However, with the aid of intravenous con- 
trast, 20xl4 mm-dilated aneurysmatic splenic artery near the splenic hilus was identified (Fig. Ia, b). While real time scanning was interpreted, the patient became further hypotensive with short periods of confusion, and signs of hypotensive shock became evident.

The patient was immediately admitted to the operating room. The exploration began laparoscopically and the perisplenic and perihepatic areas were filled with blood, and it wasdecided to move on laparatomy through a midline incision. Immediately, a massive hemorrhage was encountered and blood was hardly aspirated,and multiple laporatomy pads were required to control bleeding. Gastrocolic ligament was cut wide and a huge collection of coagulated blood was evacuated, then a bleeding arterial source was identified and compressed just behind the distal pancreas near the splenic hilus. Considering the splenic artery aneurysm on CT, splenic artery was dissected on the upper border of the pancreas and suspended with $2 / 0$ silk stay sutures for the proximal control of the hemorrhage that was promptly decreased in volume. Hemorrhage was controlled with splenectomy en bloc (Fig. 2).

The patient was accepted to the surgery ward after staying two days in the intensive care unit and discharged on postoperative fourth day uneventfully. Pathology revealed non-caseating granulomatous infiltration of the spleen pa-
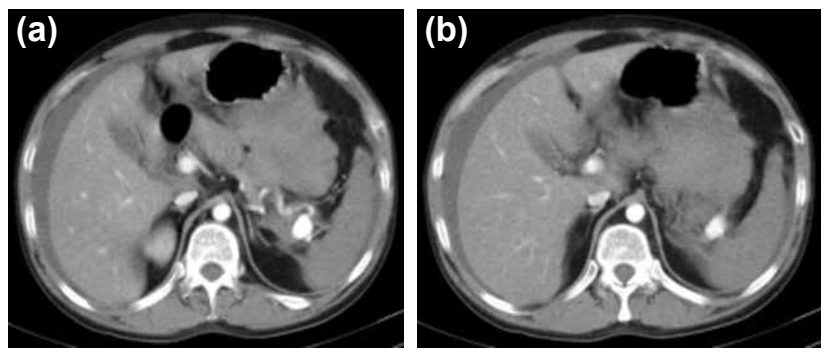

Figure 1. (a, b) Perihepatic fluid collection and aneurysmatic dilatation of the splenic artery close to the hilus.

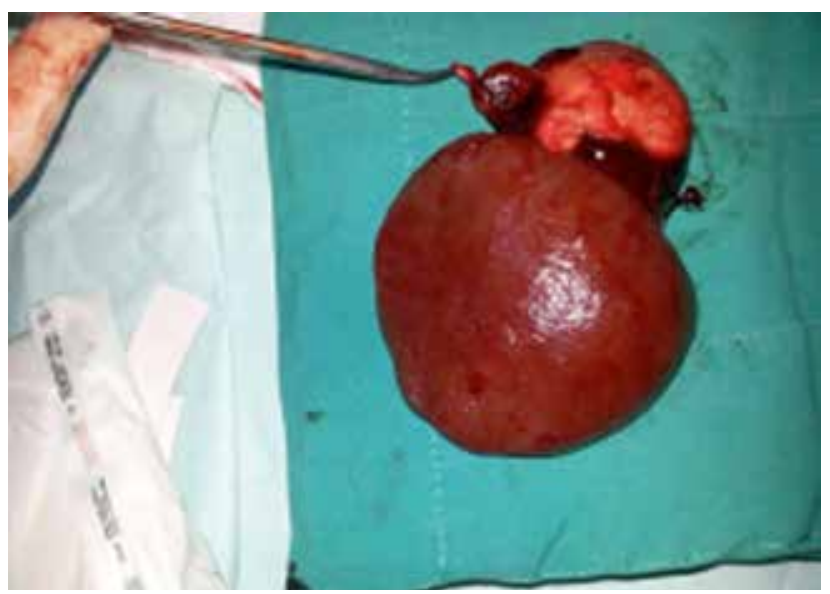

Figure 2. Splenic artery aneurysm close to the splenic hilus. renchyma consistent with sarcoidosis and hilar splenic artery aneurysm.

\section{DISCUSSION}

Although visceral arterial aneurysms are not common, SAA is the most frequent one followed by hepatic, superior mesenteric and celiac artery aneurysms. It is also the third frequent intra-abdominal aneurysm after abdominal aorta and iliac artery. The prevalence of SAA has been reported $0.8 \%$ in unselective visceral angiograms and 0.04 to 0.1 at autopsy. $[1,2]$ They are usually asymptomatic and found during unrelated diognostic imaging. Most are small saccular aneurysms at the bifurcation in the middle or distal splenic artery. Among etiologic factors, atherosclerosis, sysyemic and/or portal hypertension, trauma, and septic embolism have been reported and mycotic infections, diabetes, pregnancy also may play a role. SAAs are more frequent in women than men, with a 4:I female-to-male ratio, and commonly affect multiparous women during pregnancy. In pregnant women, compression of the aorta by the uterus is believed to increase portal congestion and increased hormone levels, estrogen and relaxin, lead to vascular intimal hyperplasia and fragmentation of the internal elastic membrane. ${ }^{[3-5]}$

The rupture of SAA may result in exsanguinating hemorrhage and the reported rate of rupture is between $3 \%$ and $9.6 \%$, and about $10 \%$ of SAAs are ruptured at the time of diagnosis with a reported mortality rate of $36-75 \% .^{[3,5]}$ Rupture and bleeding result in sudden abdominal pain and even in rapidly progressing hypovolemic shock; as it wasthe case presented here. ${ }^{[6,7]}$ In fact, SAA is a rare diagnosis in the emergency department with a prevalence of approximately $0.011 \%{ }^{[1]}$ They are usually small but aneursyms as large as $30 \mathrm{~cm}$ have been reported. Although rupture is usually directly proportionalwith size, rupture in aneurysms less than $2 \mathrm{~cm}$ in diameter is also possible. ${ }^{[2]}$

SAA rupture with intra-abdominal hemorrhage may be an unexpected finding as a part of the workup of abdominal pain. Computerized abdominal tomography (CAT) usually detects free fluid around the spleen and other viscera, and contrast media leakage or contrast enhanced hematoma may also be present. Since most aneurysms occur during late pregnancy, placental abruption is the most frequent misdiagnosis and it is usually corrected only during exploration. Patients are usually in the delivery room and complex diagnostic facilities are usually not within immediate reach. ${ }^{[2,3]}$ Rupture of the aneurysm may be difficult to diagnose intially due to the double rupture phenomenon. Rupture into the lesser omental, may tamponade bleeding intially and result in acute abdominal pain and transient hypotension, However, as bleeding continues, the lesser sac also ruptures relieving the tamponade, and massive abdominal bleeding ensues with cardiovascular collapse. ${ }^{[5]}$ It was the case we believed to have happened during the CAT examination of our patient. 
Regardless of how SAA is discovered, surgical or endovascular treatment is advocated. Patients with known SAA and related symptoms (pain, expanding aneurysm $>2.5 \mathrm{~cm}$ in diameter), SAA in women who are pregnant or expecting to be pregnant, and in liver transplantation candidates, SAA can be angiographically obliterated or surgically repaired with or without splenectomy or partial pancreatectomy. Elective repair of SAA is safe with around I.3\% mortality. Yet, emergent repair of ruptured SAA is associated with mortality of up to 40\%. ${ }^{[1]}$

The presented case is further interesting since the patient had sarcoidosis and was on steroid treatment. Rheumatologic disorders may be associated with vasculitis and several reported cases are associated with aneurysmatic splenic artery developed with vasculitic involvement. ${ }^{[7,8]}$ It is unusual for sarcoidosis to involve vessels but splenic involvement may occur as the presented case revealed non-caseating granuloma formation within the spleen and in the splenic hilus consistent with sarcoidosis but not in the vessel wall per se. ${ }^{[9]}$

Consent: Written informed consent was obtained from the patientfor publication of this case report and accompanying images.

Competing interests: The authors declare that they have no competing interests.

Authors' contributions: MTA and MMF analyzed and interpreted the patient data. MTA, MMF and ST were the major contributors in writing. $\mathrm{MO}$ and $\mathrm{BA}$ helped in searching the literature. MTA, MMF and ST were involved in treatment of the patient. KM involved in checking all the course.

\section{REFERENCES}

1. Liu CF, Kung CT, Liu BM, Ng SH, Huang CC, Ko SF. Splenic artery aneurysms encountered in the ED: 10 years' experience. Am J Emerg Med 2007;25:430-6.

2. Sadat U, Dar O, Walsh S, Varty K. Splenic artery aneurysms in pregnancy-a systematic review. Int J Surg 2008;6:261-5.

3. Chookun J, Bounes V, Ducassé JL, Fourcade O. Rupture of splenic artery aneurysm during early pregnancy: a rare and catastrophic event. Am J Emerg Med 2009;27:898.e5-6.

4. Betal D, Khangura JS, Swan PJ, Mehmet V. Spontaneous ruptured splenic artery aneurysm: a case report. Cases J 2009;2:7150.

5. Popham P, Buettner A. Arterial aneurysms of the lienorenal axis during pregnancy. Int J Obstet Anesth 2003;12:117-9.

6. Sarikaya S, Ekci B, Aktas C, Cetin A, Ay D, Demirag A. A rare clinic presentation of abdominal pain: rupture of splenic artery aneurysm: a case report. Cases J 2009;2:148.

7. Desinan L, Scott CA, Piai I, Mazzolo GM. Sudden death due to spontaneous rupture in splenic artery atypical dissection with features of vasculitis: case report and review of the literature. Forensic Sci Int 2010;200:e1-5.

8. Dolar E, Uslusoy H, Kiyici M, Gurel S, Nak SG, Gulten M, et al. Rupture of the splenic arterial aneurysm due to Behcet's disease. Rheumatology (Oxford) 2005;44:1327-8.

9. Barton JH1, Tavora F, Farb A, Li L, Burke AP. Unusual cardiovascular manifestations of sarcoidosis, a report of three cases: coronary artery aneurysm with myocardial infarction, symptomatic mitral valvular disease, and sudden death from ruptured splenic artery. Cardiovasc Pathol 2010;19:e119-23.

\section{OLGU SUNUMU - ÖZET}

\section{Spontan splenik arter anevrizma rüptürü: Klinikte nadir görülen bir akut abdomen sebebi}

Dr. Mehmet Timuçin Aydın, Dr. Mehmet Mahir Fersahoğlu, Dr. Sinan Tezer, Dr. Mehmet Okuducu, Dr. Birol Ağca, Dr. Kemal Memişoğlu

Fatih Sultan Mehmet Eğitim ve Araştırma Hastanesi, Genel Cerrahi Kliniği, İstanbul

Acil serviste nadir olarak görülen spontan splenik arter rüptürü ani başlayan akut karın ağrısını olarak ortya çıkabilir ve tanı zamanlı olarak konulamazsa yüksek mortalite ile seyreder. Karın ağrısı yakınması ile başvuran 33 yaşında erkek hastada akut batın bulguları ile tanı çalışmasında sırasında hipovolemik şoka girdi ve acil aparatomide rüptüre splenik arter anevrizması splenektomi ile kontrol altına alındı.

Anahtar sözcükler: Akut batın; anevrizma; rüptür; splenik arter.

Ulus Travma Acil Cerrahi Derg 2016;22(I):106-108 doi: 10.5505/tjtes.20I5.32654 